\title{
DETERMINATION OF SOME PHYSICAL AND CHEMICAL PROPERTIES OF WHITE, GREEN AND BLACK TEAS (CAMELLIA SINENSIS)
}

\author{
Derya Atalay*, Hande Selen Erge
}

Abant Izzet Baysal University, Faculty of Engineering and Architecture, Food Engineering Department, Campus of Gölköy Bolu-Turkey

Geliş / Received: 22.02.2017; Kabul / Accepted: 26.04.2017; Online bask1 / Published online: 14.06.2017

Atalay, D., Erge, H.S. (2017). Determination of some physical and chemical properties of white, green and black teas (Camellia sinensis). GIDA (2017) 42 (5): 494-504 doi: 10.15237/gida.GD17024

\begin{abstract}
Tea is an evergreen plant that enjoys rainy and warm climates, and classified in the Theaceae family. Tea, which is one of the most widely consumed beverages in the world, receives interest due to the flavor and aroma besides beneficial health effects. It is categorized into three major types; not fermented (green and white tea), partially fermented (oolong tea) and fermented (black tea). The objective of this study is to determine physical properties (water activity and color) and chemical properties (antioxidant activity, content of ash, total phenolics, total flavonoids, caffeine and some phenolic compounds) of white, green and black teas. Green tea stands out in terms of bioactive compounds compared to white and black tea. The reason can be explained by nonoxidation of phenolic compounds because of steam treatment to rolled leaves during the production of green tea.
\end{abstract}

Keywords: Green tea, white tea, black tea, antioxidant activity, phenolic compounds

\section{BEYAZ, YEŞILL VE SIYYAH ÇAYLARIN (CAMELLIA SINENSIS) BAZI FİZIKSEL VE KIMYASAL ÖZELLIKLERININ BELIRLENMESI}

Öz

Çay; her zaman yeşil olan, yağmurlu ve 1 lık iklimleri seven Theaceae familyasında bulunan bir bitkidir. Dünya'da en yaygın tüketilen içeceklerden biri olan çay, sağlık üzerine pozitif etkisinin yanında lezzet ve aromasından dolayı ilgi çekmektedir. Çay; fermente olmayan (yeşil ve beyaz), kısmen fermente olan (oolong) ve fermantasyona uğrayan çay (siyah) olmak üzere 3 gruba ayrılmaktadır. Bu çalışmadaki amaç; beyaz, yeşil ve siyah çayda su aktivitesi ve renk gibi fiziksel; kül, toplam fenolik, toplam flavonoid madde miktarı, antioksidan aktivite ile kafein ve bazı fenolik bileşik içeriği gibi kimyasal özelliklerin belirlenmesidir. Yeşil çay, beyaz ve siyah çaya göre biyoaktif bileşenler açısından ön plana çıkmaktadır. Bunun sebebi ise yeşil çay üretiminde kıvrılan yapraklara buhar uygulaması nedeniyle fenolik bileşiklerin okside olmaması şeklinde açıklanmaktadır.

Anahtar kelimeler: Yeşil çay, beyaz çay, siyah çay, antioksidan aktivite, fenolik bileşikler

* Corresponding author / Yazışmalarda sorumlu yazar

बderyaatalay@ibu.edu.tr, (c) (+90) 37425410 00/4845, 鴫 (+90) 3742534558 


\section{INTRODUCTION}

The tea shrub, classified in the Theaceae family and having mainly of two variaties Camellia sinensis var. sinensis and Camellia sinensis var. assamica, is a perennial, evergreen plant, leafy crop that enjoys warm and humid climates (Caffin et al. 2004; Çelik, 2006; Carloni et al. 2013). The major tea producers are Southeast Asia including China, India, Japan, Taiwan, Sri Lanka, and Indonesia and in central African countries (Lin et al. 2003; Mehra and Baker 2007). Tea cultivation in Turkey is carried out in the Eastern Black Sea Region, from the border of Georgia to Fatsa in the west (Sar1, 2010). According to Food and Agricultural Organization (FAO) in the year of 2014 data, production of tea is 5561339 tonnes in the world and 226800 tonnes in Turkey (FAOSTAT, 2017).

Freshly, plucked leaves are processed to obtain different tea products. Tea is the second most widely drink in the world after water. The reasons for popularity of tea are known as unique aroma and flavor besides, its positive health benefits like antioxidant, cholesterol lowering, anti-inflammatory, reducing risk of cancer and obesity, anti-mutagenic, antibacterial, preventive of cardiovascular diseases, antidiabetic and anti-ager (McKay et al. 2002; Çelik, 2006; Sharangi, 2009; Unachukwu et al. 2010; Kim et al. 2011; Carloni et al. 2013).

There are three types of tea according to the level of fermentation. It can be categorized into not fermented (green and white tea), semi fermented (oolong tea) and fermented (black tea) (Fig. 1) (Horzic et al. 2009; Namita et al. 2012; Carloni et al. 2013; Dias et al. 2013). To produce green tea, the young leaves are rolled and steamed to minimize oxidation and inactivate polyphenol oxidase before drying. In the production of black tea, leaves are rolled, and phenolic compounds begin to contact with polyphenol oxidase after cellular compartmentation. The $C$. sinensis leaves undergo oxidation for 90-120 min before drying. Desired colour and aroma are obtained as a result of oxidation of catechins to theaflavins (Del Rio et al. 2004; Rusak et al. 2008; Dias et al. 2013). White tea is prepared from very young tea leaves or buds covered with tiny, silvery hairs. The buds are preserved from sunlight during growth to decrease the formation of chlorophyll, for white appearance of young leaves. White tea is steamed and dried at once (Rusak et al. 2008; Dias et al. 2013).

Green tea is known 'non-fermented' tea and contains more catechins (20-30\% of the dry weight) than black tea or oolong tea (Wang et al. 2000; Kodama et al. 2010; Namita et al. 2012). Besides catechins in green tea have strong antioxidant activities in vitro and in vivo conditions, the contents of certain vitamins (vitamin $\mathrm{C}$ ) and minerals (Cr, Mn, Se and $\mathrm{Zn}$ ) of green tea also increase the antioxidant activity (Cabrera et al. 2006; Namita et al. 2012). White tea is becoming an increasingly common consumed beverage because of having a characteristic taste and a wide range of health benefits such as antioxidant, antimicrobial and anticancer effects. Its lipolytic activity and ability to inhibit adipogenesis have received particular attention especially by obesity patients (Unachukwu et al. 2010; Damiani et al. 2014). Due to possible beneficial health effects, white tea is being searched in recent years (Dias et al. 2013).

Tea is stated to contain nearly 4000 bioactive compounds of mostly polyphenols. These

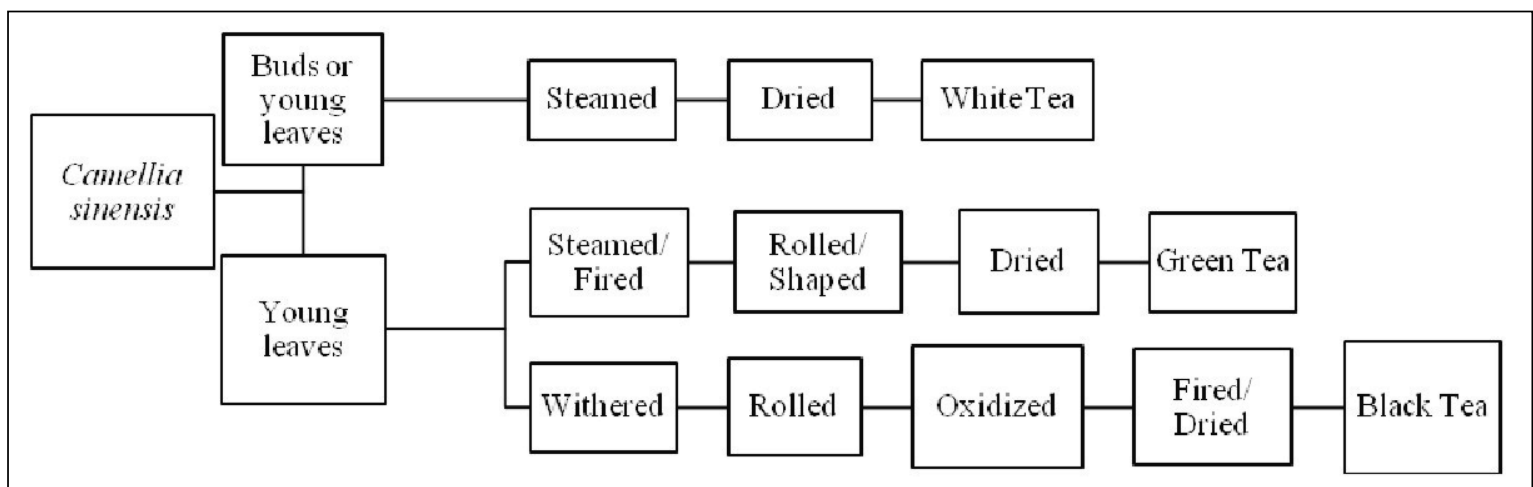

Figure 1. Schematic representation of tea production (Dias et al. 2013) 
compounds are alkaloids (caffeine and theobromine), polyphenols, amino acids, proteins, chlorophylls, carbohydrates, volatile organic compounds, fluoride, aluminum, minerals and trace elements (McKay et al. 2002; Çelik, 2006; Mahmood et al. 2010; Namita et al. 2012). Primary compounds belonging to tea polyphenols are gallic acid, catechin, gallocatechin, epicatechin, epigallocatechin, epicatechin gallate and epigallocatechin gallate (Fig. 2) (Poon, 1998; Zuo et al. 2002; Rusak et al. 2008; Horzic et al. 2009; Jeszka-Skowron et al. 2015).

It has been reported that the amount of polyphenols in tea varies depending on the variety, soil and climatic conditions, the period of shoot, the age of the plant and the processes applied during the production (Hanay, 2011). During the fermentation of $C$. sinensis leaves, monomeric flavan-3-ols (catechin and derivates) expose oxidative polymerisation converting into theaflavins as exhibited in Fig. 3 (Haslam, 2003; Kim et al. 2011). For example, the amount of monoterpene alcohols increases with the decrease in the amount of catechin during black tea production. The changes in catechins provide the characteristic flavor, color and aroma of each type of tea (Hanay, 2011).

It is known that tea polyphenols (catechins) have strong antioxidant activity, antimutagenic and anticarcinogenic effects. Among catechins, (-)-epigallocatechin gallate has the highest antioxidant activity; this is followed by (-)-epicatechingallate, (-)-epigallocatechin, (-)-epicatechin and (+)-catechin respectively (Gramza and Korczak, 2005; Hanay, 2011).

Caffeine, member of methylxanthines, which comprise theobromine (3,7-dimethylxanthine), paraxanthine (1,7-dimethylxanthine) and methyluric acids, is known as purine alkaloids and found in tea and coffee. It is reported that caffeine reduces fatigue and improves performance. However, it is also stated that excessive intake of caffeine may cause negative effects such as involuntary contraction of the muscles, coma, failure of respiration and heart, headache and migraine (Ashihara and Crozier, 2001; Khanchi et al. 2007; Smith, 2002; Wanyika et al. 2010).

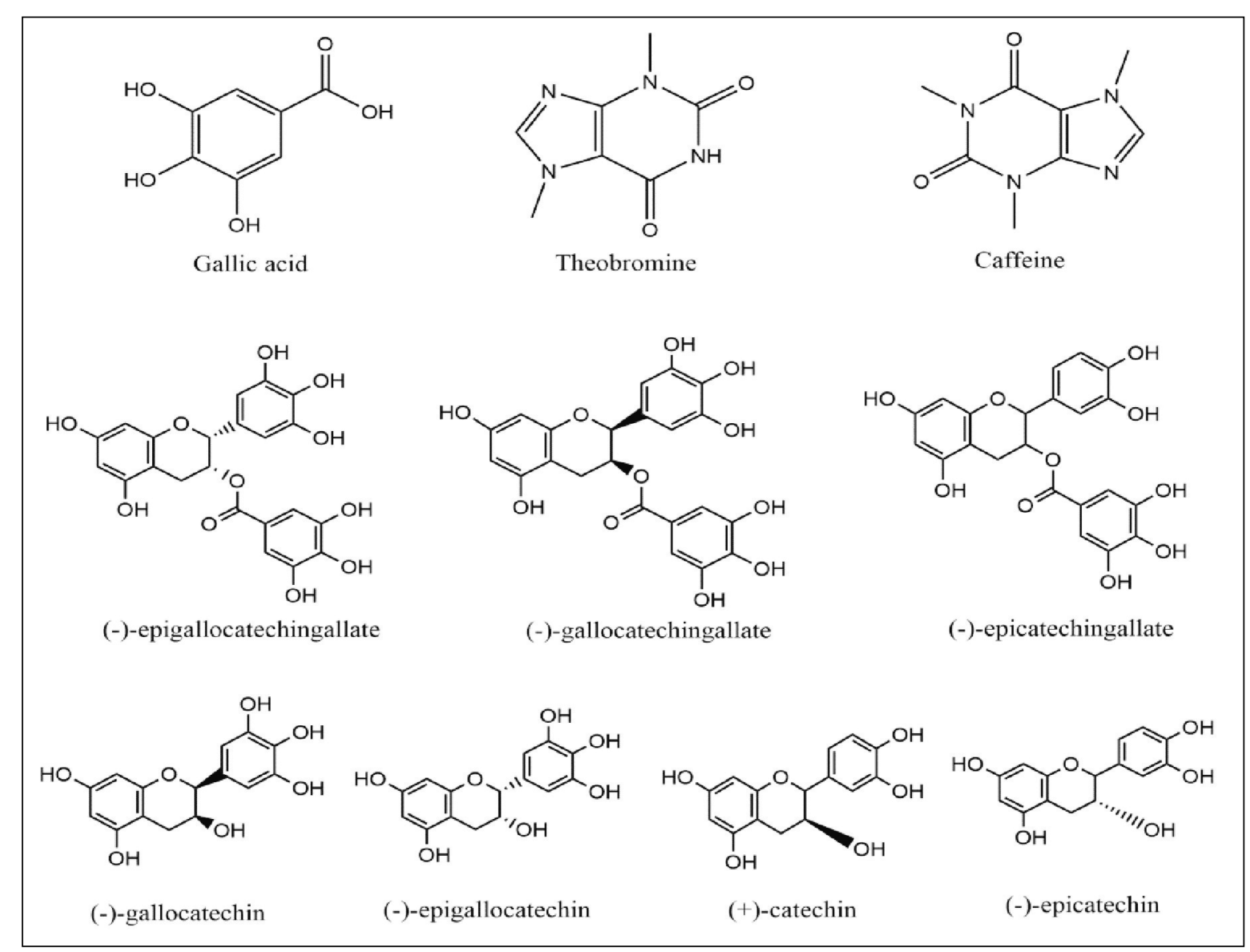

Figure 2. Molecule structure of the main components in tea (Yi et al. 2015) 


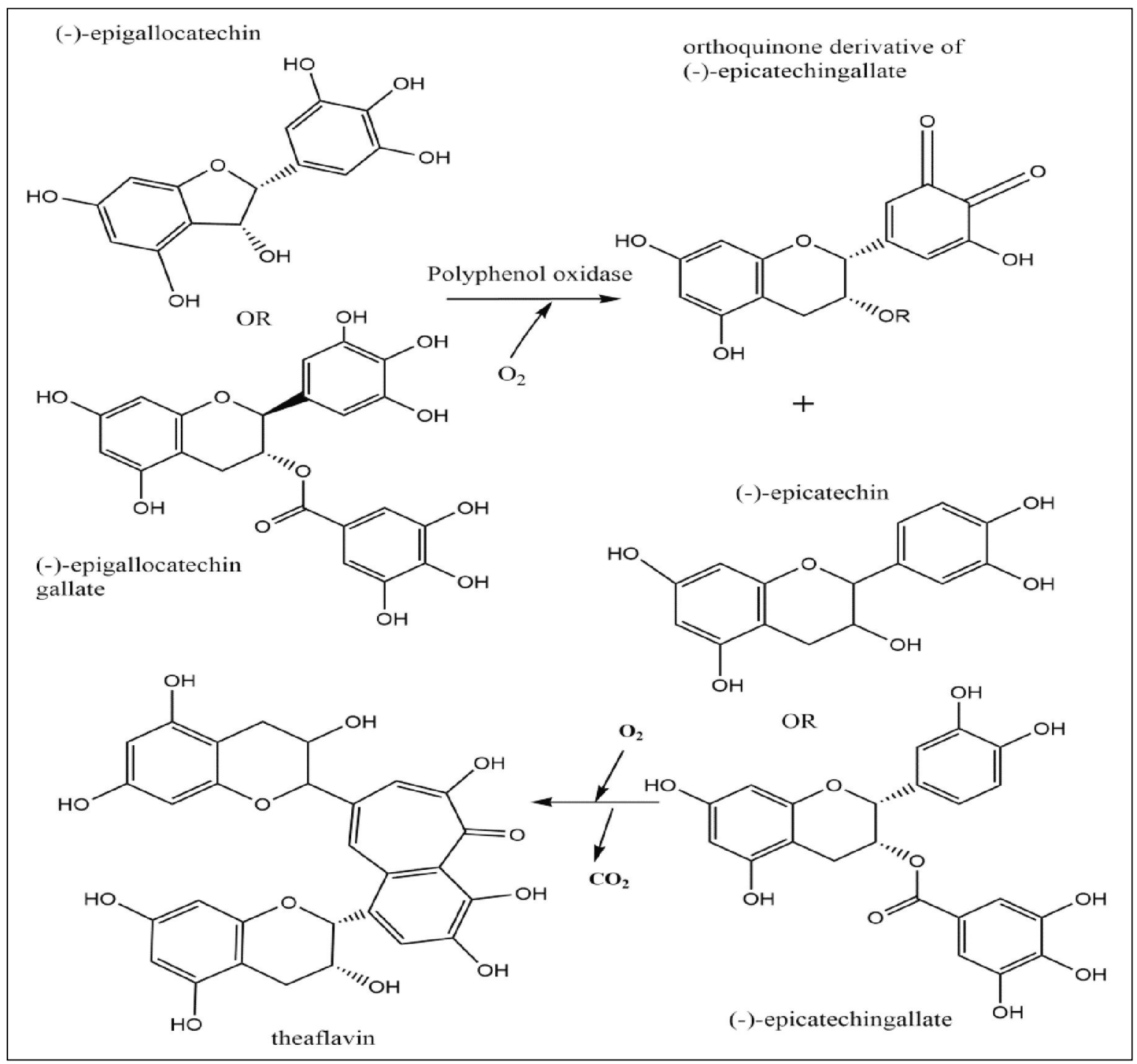

Figure 3. Oxidation of catechins to theaflavin (Kim et al. 2011)

In this study, total phenolics and total flavonoids, ash and moisture content, antioxidant activity, color, water activity, caffeine and some phenolic compounds of $1^{\text {st }}$ and $2^{\text {nd }}$ genus black tea, green and white tea obtained from Rize were determined.

\section{MATERIALS AND METHODS}

\section{Materials}

White, green and black teas ( $1^{\text {st }}$ and $2^{\text {nd }}$ genus) (Camellia sinensis) were provided from a private company in Rize, Turkey. These teas were purchased in dried form and ready to consumption. Analysis of ash and moisture content, water activity and color were carried out. Extraction method mentioned below was applied for spectrophotometric and chromatographic analyses. Content of caffeine, gallic acid, (-)-epicatechin, (-)-epigallocatechin, (-)-epigallocatechingallate, (-)-epicatechingallate and (-)-gallocatechin of teas were determined with HPLC (High Performance Liquid Chromatography). Extraction and analyses were performed with two replicates.

\section{Methods}

Moisture Analysis, Water Activity and Asb Content

AOAC (1990) and AOAC (2000) methods were used determination of moisture and ash contents of samples, respectively. The water activities of the teas were detected using a water activity meter Aqualab 3TE (Decagon, Pullman, USA). 


\section{Color}

The color characteristics of white, green and black teas were measured using CIE L*a*b* with Minolta CR-400 (Osaka, Japan). The instrument was calibrated using a white tile and the samples analyzed in triplicate. In this method; $\mathrm{L}^{*}, \mathrm{a}^{*}, \mathrm{~b}^{*}, \mathrm{C}^{*}$ (Chroma) and h (hue angle) parameters indicate lightness, redness-greenness, yellowness-blueness, color saturation and color tone, respectively (Bakker et al. 1986).

\section{Extraction}

The tea samples were extracted according to the method of Yi et al. (2015) for the determination of total phenolics and total flavonoids content, antioxidant activity, caffeine and some phenolic compounds. For each tea samples, $0.5 \mathrm{~g}$ was accurately weighted and transferred into a $50 \mathrm{~mL}$ conical flask. The tea sample was extracted with $30 \mathrm{~mL}$ of distilled water at the temperature of 100 ${ }^{\circ} \mathrm{C}$ for $10 \mathrm{~min}$. After filtration the operations were repeated two times for residue. Obtained filtrates were combined and brought in a $100 \mathrm{~mL}$ volumetric flask with distilled water. The extracts were stored at $-18^{\circ} \mathrm{C}$ until analysis.

\section{Analysis of Total Phenolics Content}

The content of total phenolics was detected by using a modified Folin-Ciocalteu colorimetric method (Shahidi et al. 2001). Firstly, $0.5 \mathrm{~mL}$ of the tea extract was mixed with $7 \mathrm{~mL}$ of distilled water in a test tube followed by the addition of $0.5 \mathrm{~mL}$ of Folin-Ciocalteu and standed for $3 \mathrm{~min}$. Then, $2 \mathrm{~mL}$ of sodium carbonate (20\%) was added and mixed well again. Absorbance of the resultant solution was read at $720 \mathrm{~nm}$ using a UV/Vis spectrophotometer (UV 1800, Shimadzu, Japan) after $1 \mathrm{~h}$ standing in an incubator (Memmert, Germany) at $25^{\circ} \mathrm{C}$. The results were expressed in gallic acid equivalents ( $\mathrm{mg} / \mathrm{g})$ using a gallic acid (50-150 mg/L) standard curve.

\section{Analysis of Total Flavonoid Content}

The content of total flavonoid of samples was determined according to the method recommended by Karadeniz et al. (2005). One milliliter of tea extract was placed in a $10 \mathrm{~mL}$ volumetric flask, and $5 \mathrm{~mL}$ of distilled water and $0.3 \mathrm{~mL}$ of $5 \%$ sodium nitrite were added and mixed. Intervals of five minutes, $0.6 \mathrm{~mL}$ of aluminum chloride hexahydrate $(10 \%)$ followed by $2 \mathrm{~mL}$ of sodium hydroxide $(1 \mathrm{~mol})$ were added and then the volume was made up to $10 \mathrm{~mL}$ with distilled water. The solution was mixed and the absorbance was measured immediately at $510 \mathrm{~nm}$ using UV/VIS spectrophotometer (UV 1800, Shimadzu, Japan). Flavonoid contents were calculated using a standard calibration curve $(50-250 \mathrm{mg} / \mathrm{L})$, prepared from (+) catechin.

\section{Trolox Equivalent Antioxidant Capacity (TEAC) by the ABTS Decolorization Assay}

The antioxidant activity was estimated by the Trolox equivalent antioxidant capacity (TEAC) method using UV/VIS spectrophotometer (Re et al. 1999). The principle of the method is based on the reduction of the ABTS*+ radical, which is a mixture of potassiumpersulphate and ABTS (2,2-azinobis (3- ethylbenzothiazoline-6-sulfonic acid) solutions, at a specified time interval. The absence of ABTS*+ was determined by measuring the decrease of absorbance at $734 \mathrm{~nm}$ for $6 \mathrm{~min}$. Results were analyzed by reference to the Trolox and expressed as micromolar Trolox equivalent antioxidant capacity ( $\mu \mathrm{M}$ Trolox/g).

\section{Analysis of DPPH Radical Scavenging Activity}

The method is based on the reduction of the relatively stable radical, DPPH, to the formation of a non-radical form in the presence of hydrogen donating antioxidant (Zhang et al. 2013). The tea samples showed antioxidant activity by the reduction of purple colored DPPH to the yellow colored diphenylpicrylhydrazine derivatives. In the analysis, different concentrations of tea extracts $(12.5 \mu \mathrm{L}-175 \mu \mathrm{L})$ was mixed with $2 \mathrm{~mL}$ of $0.1 \mathrm{mmol} / \mathrm{L}$ solution of DPPH and kept $15 \mathrm{~min}$ in the dark at room temperature. The \% inhibition values of the DPPH radical of the samples are calculated by comparison of the absorbance values $(517 \mathrm{~nm})$ read after 15 minutes. The sample concentration provided which 50\% DPPH inhibition was calculated from the equation obtained after transferring the absorbance values to the graph for different sample concentrations.

\% Inhibition: $\left(1-\mathrm{A}_{\mathrm{s}} / \mathrm{A}_{0}\right) \times 100$

$\mathrm{A}_{0}$ : the absorbance of the control

$\mathrm{A}_{\mathrm{s}}$ : the absorbance of the tested sample after $15 \mathrm{~min}$ 


\section{Determination of Caffeine and Pbenolic Compounds with HPLC}

Phenolic compounds and caffeine were separated according to method described by Yi et al. (2015) with HPLC (Flexar, Perkin Elmer). Perkin Elmer C 18 column (5 $\mu \mathrm{m}, 250$ x 4.6 mm i.d.) was operated at a temperature of $30{ }^{\circ} \mathrm{C}$, gradient elution system with a flow rate of $1 \mathrm{~mL} / \mathrm{min}$. Caffeine and phenolic compounds were detected at $250 \mathrm{~nm}$ using PDA (photodiode array) detector. Separations were carried out by varying the proportion of $0.1 \%(\mathrm{v} / \mathrm{v})$ formic acid in water (mobile phase A) and $0.1 \%$ formic acid in acetonitrile (mobile phase B). The solvent gradient elution program was as follows: to $2 \% \mathrm{~B}(\mathrm{v} / \mathrm{v})$ in $1 \mathrm{~min}$, to $30 \% \mathrm{~B}$ at $30 \mathrm{~min}$. The injection volume for all samples and standards was $20 \mu \mathrm{L}$.

\section{Identification and Calculation of Caffeine and Pbenolic Compounds}

Phenolic compounds and caffeine in white, green and black tea are described by comparison the retention times of the peaks belonging to standards and also adding the standards to the samples. Retention times obtained from the applied HPLC conditions are gallic acid (8.9 min), (-)-gallocatechin (13.7 $\mathrm{min}),(-)$-epigallocatechin (17.3 $\mathrm{min})$, caffeine (18.7 $\mathrm{min}),(-)$-epicatechin (21.7 $\mathrm{min}),(-)$-epigallocatechingallate (22 $\mathrm{min})$, (-)-epicatechingallate (26.9 $\mathrm{min})$ (Fig. 4). The concentrations were calculated using the standard calibration curves $(5-90 \mathrm{mg} / \mathrm{L})$.

\section{Statistical Analysis}

All statistical analyses were performed with SPSS for Windows (version 20.0, SPSS Inc., Chicago, Illinois). Significant differences among samples were determined using Duncan (1955) multiple range test with a $5 \%$ level of probability.

\section{RESULTS AND DISCUSSION}

In this study, content of ash, color and water activity, antioxidant activity, total phenolics, total flavonoids, caffeine and some phenolic compounds were detected in white, green and black teas and the results of the analyses are shown in Table 1.

It was determined that content of ash, which is indicative of mineral level in tea, changed between $4.868-5.3055 \%$ and the variation was found insignificant $(P>0.05)$. According to the color values, higher $\mathrm{L}^{*}$ values (brightness) were found in white (40.75) and green teas (38.21) and was statistically significant $(P<0.05)$. Lower $\mathrm{L} *$ values were present in $1^{\text {st }}(31.45)$ and $2^{\text {nd }}$ genus black teas $(31.49)(P<0.05)$. No significant variation was observed in water activity values and moisture content of white, green, $1^{\text {st }}$ black and $2^{\text {nd }}$ black teas.

The total phenolics and total flavonoids decreased following the sequence: green tea $>$ white tea $>1^{\text {st }}$ genus black tea $>2^{\text {nd }}$ genus black tea (Table 1 ) $(P<0.05)$. However, it was determined that no statistical difference between $1^{\text {st }}$ and $2^{\text {nd }}$ genus black teas $(P>0.05)$. These results can be attributed

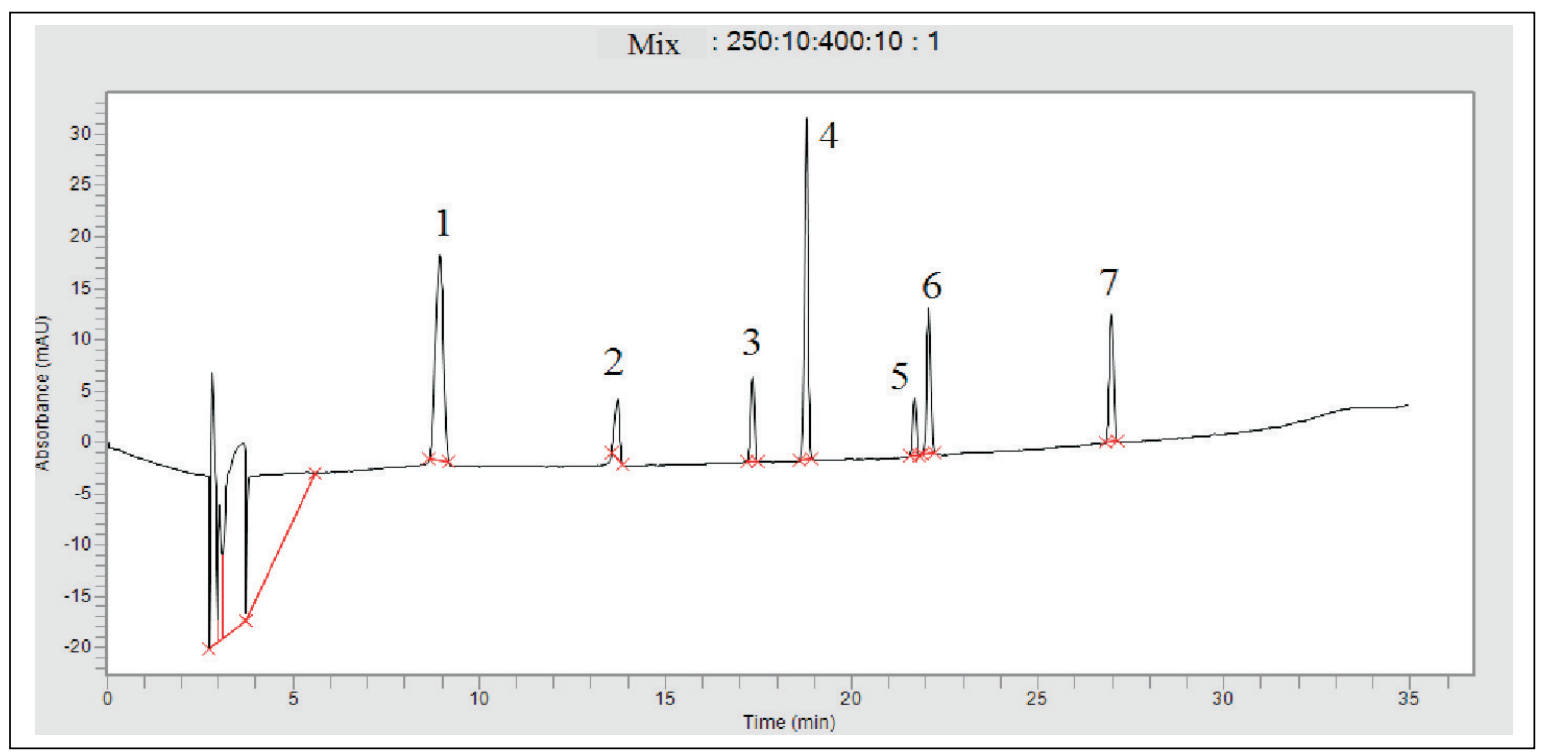

Figure 4. Chromatogram of standard mix (1: gallic acid; 2: gallocatechin; 3: epigallocatechin; 4:caffeine; 5: epicatechin; 6: epigallocatechingallate; 7 : epicatechingallate) 
to different processing methods for production of each type of tea. According to Kim et al. (2011), total phenolics content of teas (C. sinensis) reduced with gradually during tea fermentation process and was determined as $5975.81 \mathrm{mg} / \mathrm{L}$ in nonoxidized tea ( $0 \%$ oxidation, green tea) and 3752.69 $\mathrm{mg} / \mathrm{L}$ in oxidized tea ( $80 \%$ oxidation, black tea).

In this study, the higher total phenolics and flavonoids in green tea compared to white tea can be attributed to slight oxidation of white tea polyphenols during processing. White tea is commonly known nonfermented tea but this is not completely true. It is reported that white teas do not undergo the inactivation of enzymes before withering, so enzymes remain active and white tea polyphenols are oxidased slowly (Carloni et al. 2013).

The richest antioxidant activity was found in green tea $(9.7 \mu \mathrm{M} \mathrm{TE} / \mathrm{g})$; followed by white tea $(8.45$ $\mu \mathrm{M} \mathrm{TE} / \mathrm{g}), 1^{\text {st }}$ genus black tea $(4.35 \mu \mathrm{M} \mathrm{TE} / \mathrm{g})$ and $2^{\text {nd }}$ genus black tea $(2.75 \mu \mathrm{M} \mathrm{TE} / \mathrm{g})$ detected by ABTS decolorization assay $(P<0.05)$. Higher antioxidant activities of white (0.282 mg sample/ $\left.\mathrm{mL} \mathrm{EC}_{50}\right)$ and green tea $(0.073 \mathrm{mg}$ sample/mL $\mathrm{EC}_{50}$ ) were found significantly different than those of $1^{\text {st }}\left(0.509 \mathrm{mg}\right.$ sample $\left./ \mathrm{mL} \mathrm{EC}_{50}\right)$ and $2^{\text {nd }}$ genus black teas ( $0.497 \mathrm{mg}$ sample $/ \mathrm{mL} \mathrm{EC}_{50}$ ) according to DPPH method $(P<0.05) . \quad \mathrm{EC}_{50} \quad$ (Efficient Concentration) is defined as the amount of antioxidant necessary to decrease the initial DPPH concentration by $\% 50$ (Brand-Williams et al. 1995). Therefore, lower $\mathrm{EC}_{50}$ value indicates that higher antioxidant activity. Karori et al. (2007) reported black tea was at least; white tea possessed the highest antioxidant activity determined by DPPH method. The lower antioxidant activity of black tea compared to other teas is interpreted as the oxidation of catechin derivatives during production.

In a research by Carloni et al. (2013) comparing the antioxidant activity of white, green and black teas, using the ABTS, ORAC and LDL assays the following antioxidant activity was obtained: green $>$ white $>$ black. It is stated that green tea demonstrated greater content of total catechins than black tea and high catechins levels were positively correlated with antioxidant activity. Catechin contents of $1.94 \mathrm{mg} / \mathrm{mL}$ in green tea, $0.80 \mathrm{mg} / \mathrm{mL}$ in white tea and $0.24 \mathrm{mg} / \mathrm{mL}$ in black tea are reported.

Kim et al. (2011) stated that the antioxidant activities of teas are $71.08 \mu \mathrm{mol} \mathrm{TE} / \mathrm{mL}$ in green tea and $57.18 \mu \mathrm{mol} \mathrm{TE} / \mathrm{mL}$ in black tea, correlated with the total phenolics content.

Table 1. Physical and chemical properties of white, green and black teas

\begin{tabular}{|c|c|c|c|c|}
\hline & White Tea & Green Tea & $1^{\text {st }}$ Genus Black Tea & $2^{\text {nd }}$ Genus Black Tea \\
\hline Moisture Content (\%) & $5.0525 \pm 1.36$ & $4.0500 \pm 0.37$ & $4.1525 \pm 0.36$ & $3.85 \pm 0.40$ \\
\hline Ash Content (\%) & $5.1525 \pm 0.003$ & $5.3055 \pm 0.77$ & $4.868 \pm 0.085$ & $5.018 \pm 0.35$ \\
\hline \multicolumn{5}{|l|}{ Color } \\
\hline $\mathrm{L}^{*}$ & $40.75 \pm 2.77^{\mathrm{a}}$ & $38.21 \pm 0.86^{\mathrm{a}}$ & $31.45 \pm 0.08^{b}$ & $31.49 \pm 0.02^{b}$ \\
\hline$a^{*}$ & $-0.78 \pm 0.18^{c}$ & $-1.12 \pm 0.08^{c}$ & $1.99 \pm 0.02^{\mathrm{a}}$ & $1.43 \pm 0.16^{b}$ \\
\hline $\mathrm{b}^{*}$ & $6.35 \pm 0.07^{b}$ & $10.07 \pm 1.2^{\mathrm{a}}$ & $3.46 \pm 0.007^{c}$ & $2.92 \pm 0.347^{\circ}$ \\
\hline $\mathrm{C}^{*}$ & $6.40 \pm 0.04^{b}$ & $10.13 \pm 1.2^{\mathrm{a}}$ & $3.99 \pm 0.00^{\circ}$ & $2.75 \pm 0.33^{\circ}$ \\
\hline $\mathrm{h}$ & $96.35 \pm 2.27^{a}$ & $96.25 \pm 0.33^{\mathrm{a}}$ & $60.10 \pm 0.45^{\circ}$ & $64.13 \pm 0.30^{b}$ \\
\hline Water Activity $\left(a_{w}\right)$ & $0.343 \pm 0.08$ & $0.369 \pm 0.005$ & $0.333 \pm 0.017$ & $0.356 \pm 0.005$ \\
\hline Total Phenolics Content (mg/g) & $83.61 \pm 3.48^{\mathrm{b}}$ & $105.16 \pm 4.95^{\mathrm{a}}$ & $61.94 \pm 3.70^{c}$ & $58.2 \pm 4.67^{\circ}$ \\
\hline Total Flavonoids Content $(\mathrm{mg} / \mathrm{g})$ & $15.32 \pm 1.12^{b}$ & $20.56 \pm 0.46^{a}$ & $10.99 \pm 1.39^{c}$ & $8.6 \pm 1.35^{c}$ \\
\hline \multicolumn{5}{|l|}{ Antioxidant Activity } \\
\hline ABTS $(\mu \mathrm{M}$ TE/g) & $8.45 \pm 0.11^{\mathrm{b}}$ & $9.7 \pm 0.03^{\mathrm{a}}$ & $4.35 \pm 0.05^{\circ}$ & $2.75 \pm 0.12^{d}$ \\
\hline $\mathrm{DPPH}$ (mg sample/mL $\mathrm{EC}_{50}$ ) & $0.282 \pm 0.10^{b}$ & $0.073 \pm 0.02^{\mathrm{b}}$ & $0.509 \pm 0.04^{\mathrm{a}}$ & $0.497 \pm 0.09^{a}$ \\
\hline \multicolumn{5}{|l|}{ Individual Compounds (mg/g) } \\
\hline Gallic acid & $2.01 \pm 1.51$ & - & $2.38 \pm 0.14$ & $2.58 \pm 0.40$ \\
\hline Gallocatechin & $3.28 \pm 1.60^{b}$ & $6.17 \pm 0.65^{\mathrm{a}}$ & $1.02 \pm 0.02^{b}$ & $0.89 \pm 0.05^{b}$ \\
\hline Epigallocatechin & $2.31 \pm 0.36^{b}$ & $39.44 \pm 0.90^{\mathrm{a}}$ & $3.33 \pm 0.66^{b}$ & $2.48 \pm 0.22^{b}$ \\
\hline Caffeine & $35.83 \pm 3.89^{a}$ & $17.37 \pm 0.27^{b}$ & $22.34 \pm 0.88^{b}$ & $22.21 \pm 1.92^{b}$ \\
\hline Epicatechin & $1.54 \pm 0.43^{\mathrm{b}}$ & $6.99 \pm 0.08^{a}$ & $1.27 \pm 0.1^{\mathrm{b}}$ & $1.34 \pm 0.11^{\mathrm{b}}$ \\
\hline Epigallocatechingallate & $19.58 \pm 7.06^{b}$ & $44.71 \pm 1.13^{\mathrm{a}}$ & $3.96 \pm 0.07^{\circ}$ & $3.86 \pm 0.13^{\circ}$ \\
\hline Epicatechingallate & $5.59 \pm 0.54^{\mathrm{a}}$ & $5.62 \pm 0.11^{\mathrm{a}}$ & $0.661 \pm 0.04^{b}$ & $2.92 \pm 3.38^{\mathrm{ab}}$ \\
\hline
\end{tabular}

Means within a row followed by different letters are significantly different among samples $(P<0.05)$.

Values are mean \pm SD of two measurements 
In this study, antioxidant activity determined by ABTS decolorization assay was also found to be high correlated with total phenolics $(\mathrm{r}=0.959$, $P<0.05)$ and total flavonoids $(\mathrm{r}=0.965, P<0.05)$ contents of samples. These values for DPPH method among total phenolics and total flavonoids were obtained as $0.995(P<0.05)$ and $0.977(P<0.05)$, respectively.

In this research, individual phenolic compounds and caffeine content in white, green and black teas can be seen in Table 1. White tea showed significantly higher content of caffeine than that of the other samples $(P<0.05)$. The gallocatechin $(6.17 \mathrm{mg} / \mathrm{g})$, epicatechin $(6.99 \mathrm{mg} / \mathrm{g})$, epigallocatechin
$(39.44 \mathrm{mg} / \mathrm{g})$ and epigallocatechingallate ( $44.71 \mathrm{mg} / \mathrm{g}$ ) contents of green tea were found significantly higher compared with the other teas $(P<0.05)$. Epicatechingallate content of $1^{\text {st }}$ genus black tea $(0.661 \mathrm{mg} / \mathrm{g})$ was found significantly different from white $(5.59 \mathrm{mg} / \mathrm{g})$ and green tea $(5.62 \mathrm{mg} / \mathrm{g})$, whereas it is obtained similar with $2^{\text {nd }}$ genus black tea $(2.92 \mathrm{mg} / \mathrm{g})(P<0.05)$. Gallic acid was not detected in green tea, on the other hand, the difference in gallic acid among the other samples was observed insignificant $(P>0.05)$. Chromatograms of white and green teas and $1^{\text {st }}$ and $2^{\text {nd }}$ genus black teas are shown in Fig. 5 and Fig. 6.
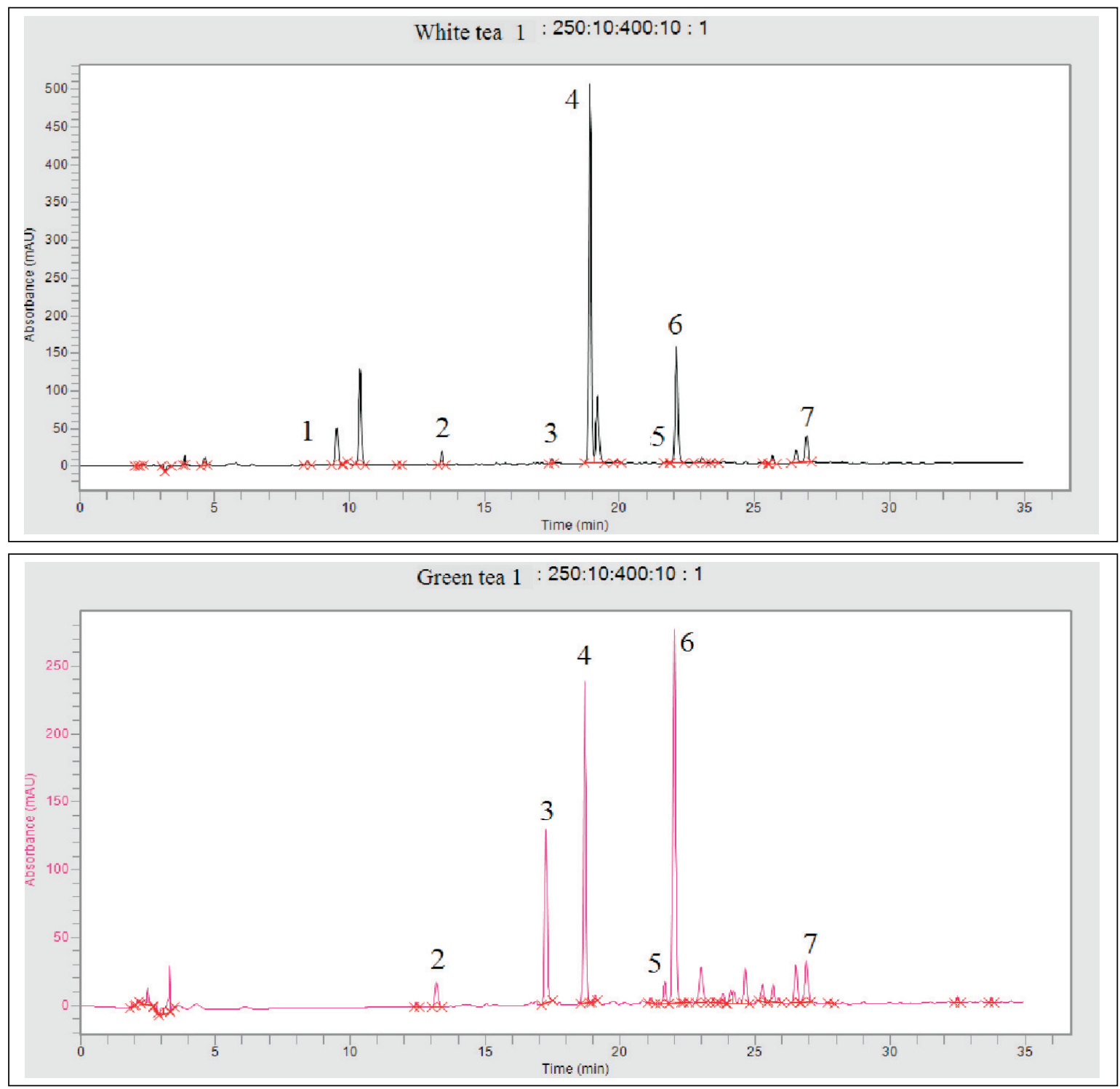

Figure 5. Chromatograms of white and green teas (1: gallic acid; 2: gallocatechin; 3: epigallocatechin; 4:caffeine; 5: epicatechin; 6: epigallocatechingallate; 7: epicatechingallate) 

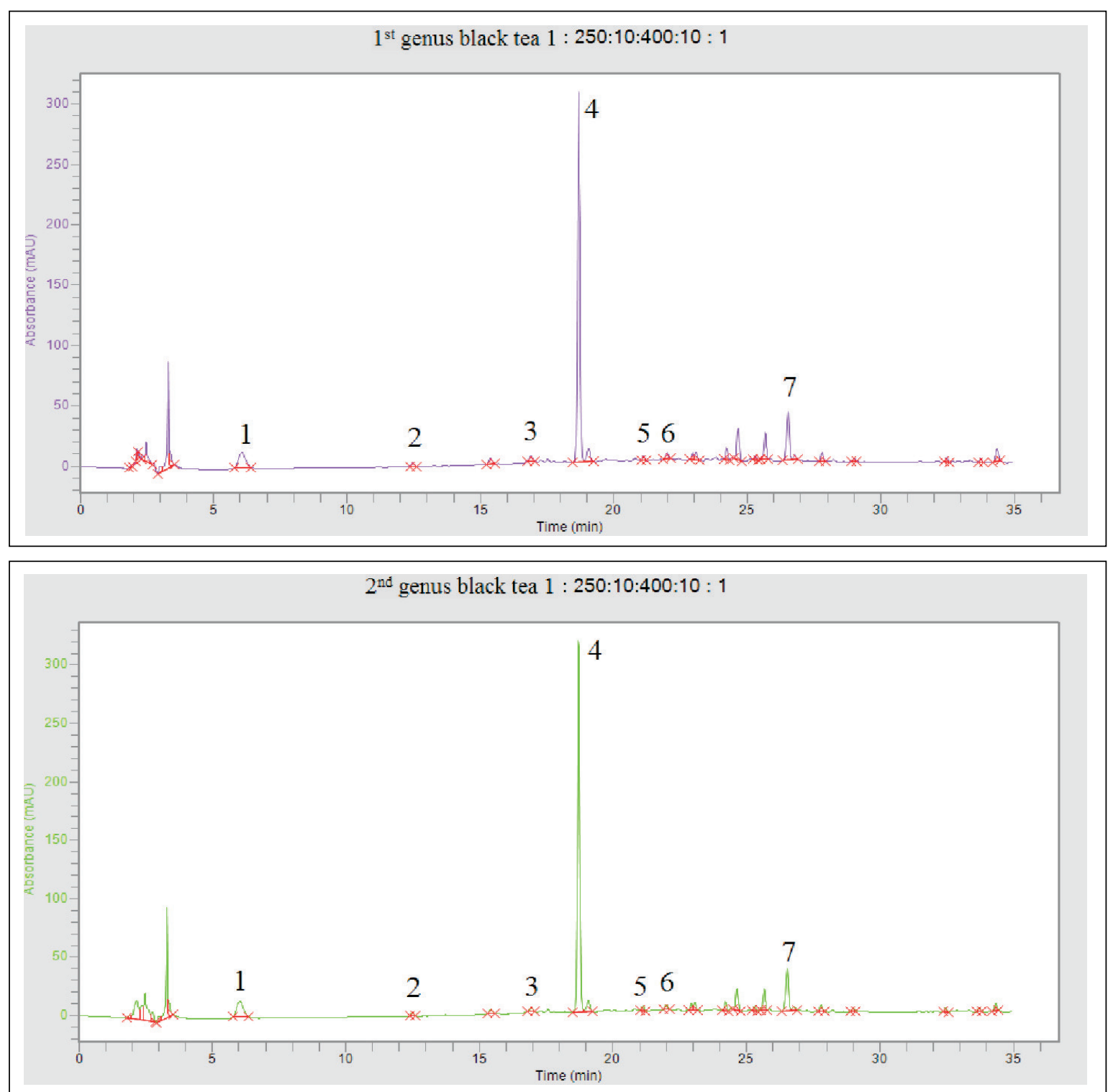

Figure 6. Chromatograms of $1^{\text {st }}$ and $2^{\text {nd }}$ genus black teas (1: gallic acid; 2: gallocatechin; 3: epigallocatechin; 4:caffeine; 5: epicatechin; 6: epigallocatechingallate; 7: epicatechingallate)

It was observed in this study that the highest level of epigallocatechin gallate was present in green tea $(44.71 \mathrm{mg} / \mathrm{g})$. Higher antioxidant activities in green tea determined by both methods can be attributed to epigallocatechin gallate content. Because, it is indicated that (-)-epigallocatechin gallate showed greater free radical scavenging capacity than the other catechins (Poon, 1998; Gramza and Korczak, 2005; Hanay, 2011).

Content of gallic acid, caffeine, theobromine, catechin and derivates were researched in green tea, white tea, black tea and the others type of tea in one study by Yi et al. (2015). According to this research, gallic acid and caffeine is the most abundant component in black tea while the content of caffeine in green tea is significantly increased compared to that in black tea. Green tea possessed the most amount of (-)-epigallocatechingallate, followed by white and black tea. It is stated that quick application of heat to stop oxidation in green tea processing provides to stable most of the catechin derivates. It is remarked that the caffeine level in black tea were similar in white and green teas by Carloni et al. (2013). 
Tea is an important source of dietary polyphenols. It is known that these compounds possess antioxidant capacity. In this research, it is pointed out that white and green tea produced in Turkey have superior potential in terms of total phenolics and total flavonoids contents, antioxidant activity and phenolic compounds than those of black tea consumed commonly.

\section{ACKNOWLEDGEMENT}

This work was supported by research grant 2015.09.04.959-2015.09.04.948 from Scientific Research Projects at Abant Izzet Baysal University, so we would like to thank for their contributions.

\section{REFERENCES}

AOAC (1990). Official methods of analysis. Association of Official Analysis Chemists. Washington DC, USA.

AOAC (2000). Official methods of analysis. Association of Official Analysis Chemists. Virginia, USA.

Ashihara, H., Crozier, A. (2001). Caffeine: a well-known but little mentioned compound in plant science. Trends Plant Sci, 6(9): 407-413.

Bakker, J., Bridle, P., Timberlake, C.F. (1986). Tristimulus measurements (CIELAB 76) of port wine colour. Vitis, 25: 67-78.

Brand-Williams, W., Cuvelier, M.E., Berset, C. (1995). Use of a free radical method to evaluate antioxidant activity. Lebensm-Wiss Technol, 28: 25-30.

Cabrera, C., Artacho, R., Gimenez, R. (2006). Beneficial effects of green tea- a review. $J \mathrm{Am}$ Coll Nutr, 25(2): 79-99.

Caffin, N., Darcy, B., Yao, L., Rintoul, G. (2004). Developing an index of quality for Australian tea. Australian Government, Rural Industries Research and Development Corporation, 192 p. ISBN: 0642587434 .

Carloni, P., Tiano, L., Padella, L., Bacchetti, T., Customu, C., Kay, A., Damiani, E. (2013). Antioxidant activity of white, green and black tea obtained from the same tea cultivar. Food Res Int, 53: 900-908.

Çelik, F. (2006). Tea (Camellia Sinensis); Composition, the preventive effects on health and consumption: Review. J Med Sci, 26: 642-648.
Damiani, E., Bacchetti, T., Padella, L., Tiano, L., Carloni, P. (2014). Antioxidant activity of different white teas: Comparison of hot and cold tea infusions. J Food Compos Anal, 33: 59-66.

Del Rio, D., Stewart, A.J., Mullen, W., Burns, J., Lean, M.E.J., Brighenti, F., Crozier, A. (2004). HPLC-MS ${ }^{n}$ Analysis of phenolic compounds and purine alkaloids in green and black tea. J Agric Food Chem, 52: 2807-2815.

Dias, T.R., Tomas, G., Teixeira, N.F., Alves, M.G., Oliveira, P.F., Silva, B.M. (2013). White tea (Camellia Sinensis (L.)): Antioxidant properties and beneficial health effects. Int J Food Sci Nutr Diet, 2(2): 1-15.

Duncan, D.B. (1955). Multiple range and multiple F-test. Biometrics, 11: 1- 42.

FAOSTAT (2017). http://www.fao.org/faostat/ en/\#data/QC (Accessed: 17 January 2017)

Gramza, A., Korczak, J. (2005). Tea constituents (Camellia sinensis L.) as antioxidants in lipid systems. Trends Food Sci Technol, 16: 351-358.

Hanay, N. (2011). Effects of different extraction time and temperature on infusion amount of phenolics and alkaloids. Akdeniz University, Institute of Science and Technology, Department of Food Engineering, Master's Thesis, Antalya, Turkey, 118 p.

Haslam, E. (2003). Thoughts on thearubigins. Phytochem, 64: 61-73.

Horzic, D., Komes, D., Belscak, A., Ganic, K.K., Ivekovic, D., Karlovic, D. (2009). The composition of polyphenols and methylxanthines in teas and herbal infusions. Food Chem, 115: 441-448.

Jeszka-Skowron, M., Krawczyk, M., ZgolaGrzeskowiak, A. (2015). Determination of antioxidant activity, rutin, quercetin, phenolic acids and trace elements in tea infusions: Influence of citric acid addition on extraction of metals. J Food Compos Anal, 40: 70-77.

Karadeniz, F., Burdurlu, H.S., Koca, N., Soyer, Y. (2005). Antioxidant activity of selected fruits and vegetables grown in Turkey. Turk J Agric For, 29: 297-303.

Karori, S.M., Wachira, F.N., Wanyoko, J.K., Ngure, R.M. (2007). Antioxidant capacity of different types of tea products. Afr J Biotechnol, 6(19): 2287-2296. 
Khanchi, A.R., Mahani, M.K., Hajihosseini, M., Maragheh, M.G., Chaloosi, M., Bani, F. (2007). Simultaneous spectrophotometric determination of caffeine and theobromine in Iranian tea by artificial neural networks and its comparison with PLS. Food Chem, 103: 1062-1068.

Kim, Y., Goodner, K.L., Park, J.D., Choi, J., Talcott, S.T. (2011). Changes in antioxidant phytochemicals and volatile composition of Camellia sinensis by oxidation during tea fermentation. Food Chem, 129: 1331-1342.

Kodama, D.H., Gonçalves, A.E.S.S., Lajolo, F.M., Genovese, M.I. (2010). Flavonoids, total phenolics and antioxidant capacity: comparison between commercial green tea preparations. Cienc Tecnol Aliment, 30(4): 1077-1082.

Lin, Y.S., Tsai, Y.J., Tsay, J.S., Lin, J.K. (2003). Factors affecting the levels of tea polyphenols and caffeine in tea leaves. J Agric Food Chem, 51: 1864-1873.

Mahmood, T., Akhtar, N., Khan, B.A. (2010). The morphology, characteristics, and medicinal properties of Camellia sinensis tea. J Med Plants Res, 4(19): 2028-2033.

McKay, D.L., Blumberg, J.B. (2002). The role of tea in human health: An update. J Am Coll Nutr, 21(1): 1-13.

Mehra, A., Baker, C.L. (2007). Leaching and bioavailability of aluminium, copper and manganese from tea (Camellia sinensis). Food Chem, 100: 1456-1463.

Namita, P., Mukesh, R., Vijay, K.J. (2012). Camellia Sinensis (Green Tea): A review. Global J Pharmacol, 6(2): 52-59.

Poon, G.K. (1998). Analysis of catechins in tea extracts by liquid chromatography- electrospray ionization mass spectrometry. J Chromatogr A, 794: 63-74.

Re, R., Pellegrini, N., Proteggente, A., Pannala, A., Yang, M., Rice-Evans, C. (1999). Antioxidant activity applying an improved ABTS radical caption decolorization assay. Free Radic Biol Med, 26: 1231-1237.

Rusak, G., Komes, D., Likic, S., Horzic, D., Kovac, M. (2008). Phenolic content and antioxidative capacity of green and white tea extracts depending on extraction conditions and the solvent used. Food Chem, 110: 852-858.
Sar1, F. (2010). Variations in theanine content during tea processing. Ankara University, Graduate School of Natural and Applied, Department of Food Engineering, Ph D. Thesis, Ankara, Turkey, $99 \mathrm{p}$.

Shahidi, F., Chavan, U.D., Naczk, M., Amarowicz, R. (2001). Nutrient distribution and phenolic antioxidants in air-classified fractions of beach pea (Lathyrus maritimus L.). J Agric Food Chem, 49: 926-933.

Sharangi, A.B. (2009). Medicinal and therapeutic potentialities of tea (Camellia sinensis L.) - A review. Food Res Int, 42: 529-535.

Smith, A. (2002). Effects of caffeine on human behavior. Food Chem Toxicol, 40(9): 1243-1255.

Unachukwu, U.J., Ahmed, S., Kavalier, A., Lyles, J.T., Kennelly, E.J. (2010). White and green teas (Camellia sinensis var. sinensis): variation in phenolic, methylxanthine, and antioxidant profiles. J Food Sci, 75(6): 541-548.

Wang, H., Provan, G.J., Helliwell, K. (2000). Tea flavonoids: their functions, utilisation and analysis. Trends Food Sci Technol, 11: 152-160.

Wanyika, H.N., Gatebe, E.G., Gitu, L.M., Ngumba, E.K., Maritim, C.W. (2010). Determination of caffeine content of tea and instant coffee brands found in the Kenya market. Afr J Food Sci, 4(6): 353-358.

Yi, T., Zhu, L., Peng, W.L., He, X.C., Chen, H.L., Li, J., Yu, T., Liang, Z.T., Zhao, Z.Z., Chen, H.B. (2015). Comparison of ten major constituents in seven types of processed tea using HPLC-DAD-MS followed by principal component and hierarchical cluster analysis. LWT-Food Sci Technol, 62: 194-201.

Zhang, Y., Li, Q., Xing, H., Lu, X., Zhao, L., Qu, K., Bi, K. (2013). Evaluation of antioxidant activity of ten compounds in different tea samples by means of an on-line HPLC-DPPH assay. Food Res Int, 53: 847-856.

Zuo, Y., Chen, H., Deng, Y. (2002). Simultaneous determination of catechins, caffeine and gallic acids in green, Oolong, black and pu-erh teas using HPLC with a photodiode array detector. Talanta, 57: 307-316. 